\title{
A randomized controlled trial of intranasal oxytocin in Phelan-McDermid syndrome
}

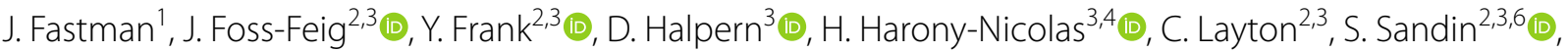

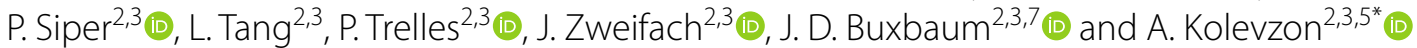

\begin{abstract}
Background: Phelan-McDermid syndrome (PMS) is a rare neurodevelopmental disorder caused by haploinsufficiency of the SHANK3 gene and characterized by global developmental delays, deficits in speech and motor function, and autism spectrum disorder (ASD). Monogenic causes of ASD such as PMS are well suited to investigations with novel therapeutics, as interventions can be targeted based on established genetic etiology. While preclinical studies have demonstrated that the neuropeptide oxytocin can reverse electrophysiological, attentional, and social recognition memory deficits in Shank3-deficient rats, there have been no trials in individuals with PMS. The purpose of this study is to assess the efficacy and safety of intranasal oxytocin as a treatment for the core symptoms of ASD in a cohort of children with PMS.

Methods: Eighteen children aged 5-17 with PMS were enrolled. Participants were randomized to receive intranasal oxytocin or placebo (intranasal saline) and underwent treatment during a 12-week double-blind, parallel group phase, followed by a 12-week open-label extension phase during which all participants received oxytocin. Efficacy was assessed using the primary outcome of the Aberrant Behavior Checklist-Social Withdrawal (ABC-SW) subscale as well as a number of secondary outcome measures related to the core symptoms of ASD. Safety was monitored throughout the study period.
\end{abstract}

Results: There was no statistically significant improvement with oxytocin as compared to placebo on the ABC-SW (Mann-Whitney $U=50, p=0.055)$, or on any secondary outcome measures, during either the double-blind or openlabel phases. Oxytocin was generally well tolerated, and there were no serious adverse events.

Limitations: The small sample size, potential challenges with drug administration, and expectancy bias due to relying on parent reported outcome measures may all contribute to limitations in interpreting results.

Conclusion: Our results suggest that intranasal oxytocin is not efficacious in improving the core symptoms of ASD in children with PMS.

Trial registration NCT02710084.

Keywords: Phelan-McDermid syndrome, PMS, Shank3, Autism spectrum disorder, ASD, Oxytocin

\footnotetext{
*Correspondence: alexander.kolevzon@mssm.edu

${ }^{2}$ Seaver Autism Center for Research and Treatment, Icahn School

of Medicine at Mount Sinai, One Gustave L. Levy Place, Box 1230, New York, NY 10029, USA

Full list of author information is available at the end of the article
}

\section{Background}

Gene discovery approaches, followed by functional analysis using model systems, have clarified the neurobiology of several genetic subtypes of autism spectrum disorder (ASD) and led to important opportunities for developing novel therapeutics [44, 48, 60,77]. ASD is now understood to have multiple distinct genetic risk loci, and one original author(s) and the source, provide a link to the Creative Commons licence, and indicate if changes were made. The images or other third party material in this article are included in the article's Creative Commons licence, unless indicated otherwise in a credit line to the material. If material is not included in the article's Creative Commons licence and your intended use is not permitted by statutory regulation or exceeds the permitted use, you will need to obtain permission directly from the copyright holder. To view a copy of this licence, visit http://creativecommons.org/licenses/by/4.0/. The Creative Commons Public Domain Dedication waiver (http://creativeco mmons.org/publicdomain/zero/1.0/) applies to the data made available in this article, unless otherwise stated in a credit line to the data. 
example is $S H A N K 3$, where haploinsufficiency through deletion or sequence variants causes Phelan-McDermid syndrome (PMS), which is characterized by global developmental delay, motor skills deficits, delayed or absent speech, and ASD [71]. SHANK3 is the critical gene in this syndrome $[15,16,29]$, and studies indicate that loss of one copy of SHANK3 causes a monogenic form of ASD with a frequency of at least $0.5 \%$ of ASD cases and up to $2 \%$ of ASD with moderate to profound intellectual disability [53]. SHANK3 codes for a master scaffolding protein in postsynaptic glutamatergic synapses and plays a critical role in synaptic function [14]. Using Shank3-deficient mice and rats, specific deficits in synaptic function and plasticity in glutamate signaling have been identified [17, 42, 44, 45, 47, 59, 70, 81]. Importantly, studies in Shank3-deficient rats have demonstrated that oxytocin reverses synaptic plasticity deficits in the hippocampus and the medial prefrontal cortex, in addition to reversing behavioral deficits in long-term social recognition memory and attention [45]. Furthermore, oxytocin has recently been shown to stimulate neurite outgrowth and increase gene expression of Shank3 protein in human neuroblastoma cells [84] and to reverse neurite abnormalities in Shank3-deficient mice [65].

Oxytocin is an FDA-approved, commercially available medication that can be compounded into an intranasal solution for passage through the blood-brain barrier (BBB). Oxytocin is the brain's most abundant neuropeptide; it can act as a classical neurotransmitter, a neuromodulator, and a hormone with actions throughout the body [10, 36, 78]. In animal models, oxytocin has been demonstrated to increase social approach behavior, social recognition, social memory, and to reduce stress responses [18, 21, 52]. In humans, oxytocin is known as a strong modulator of social behavior and increases gaze to eye regions, social cognition, social memory, empathy, perceptions of trustworthiness, and cooperation within one's own group $[9,11,22-25,28,34,35,38,39,49-51$, $58,63,66,67,68,75,76,83]$.

Studies of intranasal oxytocin suggest equivocal effects on social behavior both generally and in $\operatorname{ASD}[5,6,22$, 24-27, 40, 41, 62, 74, 82, 83]. The largest study in ASD to date did not demonstrate a significant improvement in social behavior with intranasal oxytocin [69]. There are many proposed reasons why oxytocin has proven unreliable in ASD, including due to issues around brain penetrance, dosing, and trial design $[1,54,61]$. However, the clinical and etiological heterogeneity of ASD pose prominent obstacles for successful clinical trials in ASD in general and likely contributes to challenges detecting consistent effects with oxytocin. While it is necessary to exercise caution in interpreting the literature to date as justification for the current trial, we sought to address this issue of heterogeneity by recruiting a sample population with a shared underlying genetic etiology. The following study was conducted to assess the safety and efficacy of oxytocin in children with PMS, all of whom had a deletion or pathogenic sequence variant of the SHANK3 gene. We hypothesized that individuals with PMS would show improvement in social withdrawal symptoms following oxytocin administration.

\section{Methods}

We used a double-blind, placebo-controlled parallel group design in 18 children with PMS, aged 5 to 17 years old, to evaluate the impact of oxytocin on impairments in socialization, language, and repetitive behaviors. The study protocol was approved by the Mount Sinai Program for the Protection of Human Subjects, and all caregivers signed informed consent. Participants were enrolled between May 2016 and November 2019 and randomized to receive either intranasal oxytocin or matching placebo (intranasal saline) for 12 weeks during the double-blind phase, followed by a 12-week open-label extension with intranasal oxytocin.

All participants had pathogenic deletions encompassing SHANK3 $(n=12)$ or SHANK3 sequence variants $(n=6)$. Among participants with deletions, two had ring chromosome 22. The mean deletion size was $3.1 \mathrm{Mb}$ (range $=55 \mathrm{~Kb}-8.2 \mathrm{Mb} ; \mathrm{SD}=2.7 \mathrm{Mb}$ ). Among participants with sequence variants, three had p.Ala1227Glyfs"69, two had p.Leu1142Valfs"153, and one had p.Ile1094Thrfs*100. Seventeen of 18 participants met criteria for ASD based on clinical consensus using the Autism Diagnostic Observation Schedule, Second Edition (ADOS-2) [56], the Autism Diagnostic Interview-Revised (ADI-R) [55], and the Diagnostic Manual for Mental Disorders, Fifth Edition (DSM-5; [4]).

The primary outcome measure was the Aberrant Behavior Checklist-Social Withdrawal subscale (ABCSW; [2]) and was selected to capture a core symptom domain in ASD. Secondary outcome measures included the Repetitive Behavior Scale-Revised (RBS-R, [13]), the Short Sensory Profile (SSP, [30]), the Macarthur-Bates Communicative Development Inventory (MCDI, [32, 33]), the Vineland Adaptive Behavior Scales, Second Edition [73], the Clinical Global Impression-Improvement Scales (CGI-I, [43]), and the Mullen Scales of Early Learning (MSEL; [57]). The MSEL was chosen to assess cognitive ability as recommended in individuals with PMS who are often unable to complete standardized IQ tests [72], developmental quotients were calculated as previously described in the literature [31] to evaluate baseline ability, and age equivalents were used to assess change with treatment. 
Additional exploratory measures were administered using electrophysiology and eye tracking paradigms, and if feasibility is established, results will be reported in a subsequent publication.

To be eligible to participate, all participants had a minimum raw score of 12 on the ABC-SW at enrollment, which was selected by adding approximately one standard deviation to the mean ABC-SW subscale score derived from a normative sample of 601 children aged 6-17 with intellectual disability [19] and as suggested by Aman and Singh [3]. All participants were on stable medication regimens for at least three months prior to enrollment and throughout the study period.

\section{Drug administration}

Oxytocin was delivered in 5-ml bottles with a dosage pump manufactured by Novartis in Europe and marketed as Syntocinon ${ }^{\mathrm{TM}}$ under an Investigational New Drug Application (IND) from the FDA (IND \#104496). The first seven participants started the trial with a dose of 24 international units (IU) twice daily (BID), which was adjusted to 12 IU BID after two participants experienced increased irritability. Subsequently, after the first two-week check-in call, if the drug was well tolerated, the dose was increased to 24 IU BID. Each insufflation delivered $4 \mathrm{IU}$ and three insufflations (12 IU) in each nostril were given twice daily for a total daily dose of 48 IU. The dose of 24 IU BID was chosen because it is the most commonly used in the literature in sample populations with ASD [5, 6, 40, 41, 62, 74]. Identical doses were used during the open-label treatment phase. Adherence to treatment was assessed by caregiver report and drug diary. Randomization and blinding was performed by the Mount Sinai Research Pharmacy. Caregivers received written instructions for how to administer the study drug, and the first dose was administered by the principal investigator with the caregiver observing.

Efficacy and safety measurements were taken at baseline, and at weeks 4,8 , and 12 of each treatment phase (double blind and open-label). An additional safety assessment was done at week 2 in both phases. Monitoring of adverse events (AEs) was done using an adapted semi-structured interview, the Safety and Monitoring Uniform Report Form (SMURF). AEs were documented with respect to severity, duration, management, relationship to study drug, and outcome. Severity was graded using a scale of mild, moderate, or severe. Primary and secondary outcomes were administered by an independent evaluator (DH), who was blind to side effects to prevent the risk of bias.

\section{Data analysis}

All statistical computing was performed in SPSS Version 27. Analyses were performed on the intent-to-treat population. All data were explored for outliers and data quality using descriptive statistics and graphs prior to breaking of the blind and any statistical hypothesis testing. For data on a categorical scale, we used contingency tables and histograms, and for data on a continuous scale, box-and-whisker plots.

We tested for differences in change from baseline to week 12 of the primary efficacy variable, $\mathrm{ABC}-\mathrm{SW}$, as well as all other variables by calculating the Mann-Whitney $\mathrm{U}$ test [46]. The Mann-Whitney U test is a nonparametric test robust to single gross outliers and does not require the data to follow any particular data distribution. We compared within subject changes from week 12 to 24 by calculating the Wilcoxon signed rank test [80]. In supplementary analyses, we fitted generalized linear regression models assuming data to follow an approximate normal distribution, which allowed us to include and adjust for the baseline value. All tests of statistical hypotheses were done on the two-sided 5\% level of significance and were completed while remaining blind to treatment assignments. After selecting a single primary efficacy variable, we did not adjust for multiplicity of statistical tests. However, all raw $p$-values are provided for any post hoc adjustment.

\section{Missing data}

In the case of two participants who dropped out after week 4 , difference scores were calculated for each outcome measure using the last observation carried forward. Two participants dropped out after baseline and were not included in the efficacy analysis (see Safety section).

\section{Results}

\section{Double-Blind phase: baseline to week 12}

Baseline characteristics were similar between groups, with the exception of ABC-SW scores (Table 1). Sixteen participants were included in the efficacy analysis (See CONSORT diagram; Additional file 2: figure 2). There was no statistically significant difference between oxytocin and placebo groups on change from baseline to week 12 on the ABC-SW, our primary outcome $(U=50$, median placebo change $=-7$; median oxytocin change $=-3$; $p=0.055$ ) (Fig. 1). This result did not change in a regression analysis controlling for baseline differences in ABCSW score $(F=3.41, p=0.088)$ or after removing the two participants who dropped out after week $4(U=39.5$, $p=0.053)$. In addition, there were no statistically significant differences between groups for any of our secondary outcomes during the double-blind phase (Table 2). 
Table 1 Participant baseline characteristics

\begin{tabular}{|c|c|c|c|c|c|c|c|}
\hline \multirow[t]{2}{*}{ Sex } & $\begin{array}{l}\text { Placebo }(\mathrm{N}=10) \\
N \\
\text { F: } 5 \\
\text { M: } 5\end{array}$ & \multirow[t]{2}{*}{ Range } & $\begin{array}{l}\text { Oxytocin } \\
(\mathrm{N}=8) \\
N \\
\mathrm{~F}: 4 \\
\mathrm{M}: 4 \\
\end{array}$ & \multirow[t]{2}{*}{ Range } & $\begin{array}{l}\text { Total }(\mathrm{N}=18) \\
N \\
\text { F: } 9 \\
\text { M: } 9\end{array}$ & \multirow[t]{2}{*}{ Range } & \multirow[t]{2}{*}{$p$-value } \\
\hline & Mean (SD) & & Mean (SD) & & Mean (SD) & & \\
\hline Age (years) & $9.8(3.6)$ & $6-17$ & $6.8(1.4)$ & $5-9$ & $8.4(3.2)$ & $5-17$ & 0.055 \\
\hline $\begin{array}{l}\text { Baseline ABC- } \\
\text { SW }\end{array}$ & $20.1(6.1)$ & $12-30$ & $14(3.4)$ & $12-20$ & $17.4(5.9)$ & $12-30$ & $0.012^{*}$ \\
\hline Verbal DQ & $14.9(12.8)$ & $4-46$ & $26.4(21.3)$ & $8-61$ & $20(17.6)$ & $4-61$ & 0.203 \\
\hline Nonverbal DQ & $20.1(11.7)$ & $4-42$ & $26.1(13.1)$ & $11-50$ & $22.7(12.3)$ & $4-50$ & 0.408 \\
\hline Full Scale DQ & $17.4(11.8)$ & $5-44$ & $26.3(16.7)$ & $10-50$ & $21.4(14.5)$ & $5-50$ & 0.173 \\
\hline
\end{tabular}

$A B C$-SW Aberrant Behavior Checklist Social Withdrawal subscale; $D Q$ developmental quotient; $F$ female; $M$ male; $N$ sample size; $S D$ standard deviation

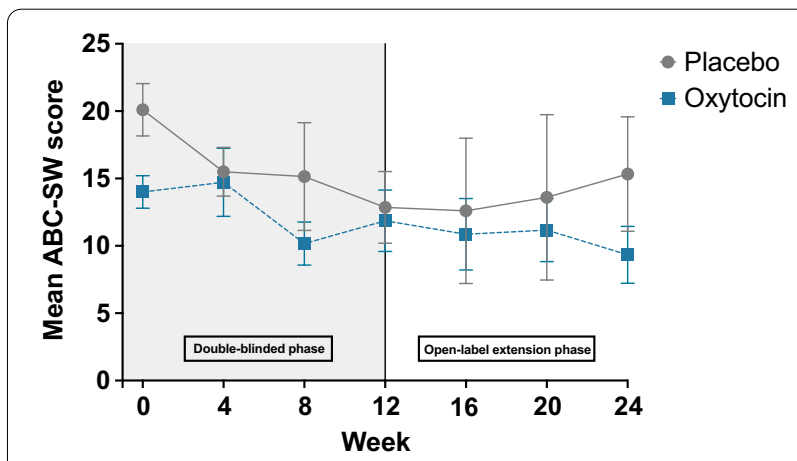

Fig. 1 Mean scores on the Aberrant Behavior Checklist Social Withdrawal subscale across study visits. Bars represent standard error

\section{Safety}

Eighteen participants were included in the safety analysis. Oxytocin was generally well tolerated, and there was no statistically significant difference between groups in the frequency of AEs $(U=37, p=0.83)$. Three participants withdrew from the study during the doubleblind phase due to tolerability concerns: one participant developed croup and a sinus infection (placebo) and the caregivers stopped the study drug on their own; two participants developed worsening irritability (one placebo; one oxytocin) and withdrew in consultation with the principal investigator. A fourth participant dropped out after receiving a single dose of study drug (placebo) due to concerns unrelated to tolerability (Additional file 2: figure 2). There were no serious adverse events (Table 3).

\section{Discussion}

The results of this small study do not support the use of intranasal oxytocin in PMS. Despite promising preclinical data and a plausible biological rationale, attempts to reduce genetic heterogeneity by selecting only participants with PMS were not adequate to identify a population in which oxytocin treatment would show more uniform impact on social behavior. The lack of a treatment effect highlights the challenges in translating from animal and other preclinical models to humans. While preclinical models may show strong construct validity, outcome measures, dosing, and bioavailability are difficult to replicate in humans. Outcome measures in preclinical studies have the advantage of enhanced objectivity and quantifying change, while clinical studies in ASD rely mainly on parent-report measures which capture ratings of behavior using relatively broad questions and are vulnerable to subjective bias. Further, while most of the outcome measures used in this study, including the ABC-SW, have been carefully validated in ASD and
We further examined within-subject change on all outcome measures during the open-label phase of the trial for each group individually and across all participants. There were no statistically significant improvements on any outcome measure between week 12 and week 24 in either group or across all participants. 
Table 2 Comparison across groups of mean change from baseline to week 12

\begin{tabular}{|c|c|c|c|c|c|c|c|c|c|}
\hline Measure & Variable name & $\begin{array}{l}\text { Number of } \\
\text { subjects } \\
\text { placebo }\end{array}$ & $\begin{array}{l}\text { Mean } \\
\text { change } \\
\text { placebo }\end{array}$ & $\begin{array}{l}\text { Median } \\
\text { change } \\
\text { placebo }\end{array}$ & $\begin{array}{l}\text { Number of } \\
\text { subjects } \\
\text { oxytocin }\end{array}$ & $\begin{array}{l}\text { Mean } \\
\text { change } \\
\text { oxytocin }\end{array}$ & $\begin{array}{l}\text { Median } \\
\text { change } \\
\text { oxytocin }\end{array}$ & $\begin{array}{l}\text { Mann- } \\
\text { Whitney U test } \\
\text { statistic }\end{array}$ & $\begin{array}{l}\text { Two- } \\
\text { sided } \\
\text { p-value }\end{array}$ \\
\hline \multicolumn{10}{|l|}{$A B C$} \\
\hline & Irritability & 9 & -5 & -3 & 7 & -1.71 & 0 & 40.5 & 0.351 \\
\hline & $\begin{array}{l}\text { Social with- } \\
\text { drawal }\end{array}$ & 9 & -7.44 & -7 & 7 & -2.42 & -3 & 50 & 0.055 \\
\hline & Stereotypy & 9 & -2.22 & -1 & 7 & 0.57 & 0 & 41.5 & 0.299 \\
\hline & Hyperactivity & 9 & -8.11 & -6 & 7 & -2.71 & 0 & 42 & 0.299 \\
\hline & $\begin{array}{l}\text { Inappropriate } \\
\text { speech }\end{array}$ & 9 & -1.67 & 0 & 7 & -7.14 & 0 & 35 & 0.758 \\
\hline \multicolumn{10}{|l|}{ RBS-R } \\
\hline & $\begin{array}{l}\text { Stereotypic } \\
\text { behaviors }\end{array}$ & 9 & -1.67 & -2 & 7 & 0.29 & 0 & 43 & 0.252 \\
\hline & Self-injury & 9 & -1.22 & 0 & 7 & 1 & 0 & 46 & 0.142 \\
\hline & $\begin{array}{l}\text { Compulsive } \\
\text { behaviors }\end{array}$ & 9 & -1.56 & 0 & 7 & -0.14 & 0 & 38 & 0.536 \\
\hline & $\begin{array}{l}\text { Ritualistic } \\
\text { behaviors }\end{array}$ & 9 & -1.33 & -1 & 7 & -0.43 & 0 & 39 & 0.47 \\
\hline & $\begin{array}{l}\text { Sameness } \\
\text { behaviors }\end{array}$ & 9 & -2 & -1 & 7 & -0.29 & -1 & 41 & 0.351 \\
\hline & $\begin{array}{l}\text { Restricted } \\
\text { behaviors }\end{array}$ & 9 & -1.43 & 0 & 7 & 0.14 & 0 & 23.5 & 0.902 \\
\hline & Overall score & 9 & -8.56 & -3 & 7 & 0 & 0 & 46 & 0.142 \\
\hline \multicolumn{10}{|l|}{ CGI-I } \\
\hline & Severity & 9 & -0.11 & 0 & 7 & -0.14 & 0 & 30.5 & 0.918 \\
\hline & Improvement* & 9 & $\mathrm{~N} / \mathrm{A}$ & N/A & 7 & $\mathrm{~N} / \mathrm{A}$ & $\mathrm{N} / \mathrm{A}$ & 38 & 0.536 \\
\hline \multicolumn{10}{|l|}{ SSP } \\
\hline & Tactile & 9 & 2.56 & 2 & 7 & 1.57 & 0 & 29 & 0.837 \\
\hline & Taste/smell & 9 & 1.67 & 0 & 7 & 0.71 & 0 & 28.5 & 0.758 \\
\hline & Movement & 9 & -0.67 & 0 & 7 & 0.29 & 0 & 41.5 & 0.299 \\
\hline & $\begin{array}{l}\text { Under-respon- } \\
\text { sive/seeks } \\
\text { sensation }\end{array}$ & 9 & 4.44 & 6 & 7 & 0.71 & 2 & 19 & 0.21 \\
\hline & $\begin{array}{l}\text { Auditory filter- } \\
\text { ing }\end{array}$ & 9 & 4 & 3 & 7 & 0.29 & -1 & 16 & 0.114 \\
\hline & $\begin{array}{l}\text { Low energy/ } \\
\text { weak }\end{array}$ & 9 & 1.67 & 2 & 7 & -0.71 & 0 & 24 & 0.47 \\
\hline & $\begin{array}{l}\text { Visual/auditory } \\
\text { sensitivity }\end{array}$ & 9 & 1.89 & 3 & 7 & -0.86 & 0 & 13 & 0.055 \\
\hline & Total & 9 & 14.33 & 8 & 7 & 1 & -8 & 14.5 & 0.071 \\
\hline \multicolumn{10}{|c|}{ Vineland-II } \\
\hline & $\begin{array}{l}\text { Communica- } \\
\text { tion }\end{array}$ & 7 & 4 & 0 & 6 & 2.83 & 2 & 22 & 1 \\
\hline & Daily living skills & 7 & 3.29 & 1 & 6 & 1.17 & 0.5 & 14.5 & 0.366 \\
\hline & Socialization & 7 & 3 & 1 & 6 & -0.5 & -0.5 & 12 & 0.234 \\
\hline & Motor & 6 & 1 & 0 & 6 & 3.17 & 0 & 20.5 & 0.699 \\
\hline & $\begin{array}{l}\text { Adaptive } \\
\text { behavior com- } \\
\text { posite }\end{array}$ & 7 & 3.14 & 2 & 6 & 2 & 2 & 21 & 1 \\
\hline & Internalizing & 7 & -1.14 & -1 & 6 & -0.5 & 0 & 29 & 0.295 \\
\hline & Externalizing & 7 & -1.14 & -1 & 6 & -0.17 & 0 & 25.5 & 0.534 \\
\hline & Maladaptive & 6 & -1.33 & 0 & 6 & -0.5 & -0.5 & 18 & 1 \\
\hline \multicolumn{10}{|l|}{ MSEL } \\
\hline & Gross motor & 7 & -1.57 & 0 & 7 & -0.86 & 0 & 22 & 0.805 \\
\hline
\end{tabular}


Table 2 (continued)

\begin{tabular}{|c|c|c|c|c|c|c|c|c|c|}
\hline Measure & Variable name & $\begin{array}{l}\text { Number of } \\
\text { subjects } \\
\text { placebo }\end{array}$ & $\begin{array}{l}\text { Mean } \\
\text { change } \\
\text { placebo }\end{array}$ & $\begin{array}{l}\text { Median } \\
\text { change } \\
\text { placebo }\end{array}$ & $\begin{array}{l}\text { Number of } \\
\text { subjects } \\
\text { oxytocin }\end{array}$ & $\begin{array}{l}\text { Mean } \\
\text { change } \\
\text { oxytocin }\end{array}$ & $\begin{array}{l}\text { Median } \\
\text { change } \\
\text { oxytocin }\end{array}$ & $\begin{array}{l}\text { Mann- } \\
\text { Whitney U test } \\
\text { statistic }\end{array}$ & $\begin{array}{l}\text { Two- } \\
\text { sided } \\
\text { p-value }\end{array}$ \\
\hline & Visual reception & 7 & 0.29 & 0 & 7 & 2.86 & 4 & 34 & 0.259 \\
\hline & Fine motor & 7 & -0.29 & 0 & 7 & 0.71 & 0 & 32 & 0.383 \\
\hline & $\begin{array}{l}\text { Receptive } \\
\text { language }\end{array}$ & 7 & -1.86 & -1 & 7 & 1.71 & 1 & 35.5 & 0.165 \\
\hline & $\begin{array}{l}\text { Expressive } \\
\text { language }\end{array}$ & 7 & 0.43 & 0 & 7 & 0.43 & 0 & 22 & 0.805 \\
\hline \multicolumn{10}{|l|}{ MCDI } \\
\hline & $\begin{array}{l}\text { Phrases under- } \\
\text { stood }\end{array}$ & 7 & 0.71 & 0 & 7 & 1.43 & 0 & 29.5 & 0.535 \\
\hline & $\begin{array}{l}\text { Words under- } \\
\text { stood }\end{array}$ & 7 & -8.14 & 0 & 7 & 7 & 1 & 29 & 0.62 \\
\hline & $\begin{array}{l}\text { Words pro- } \\
\text { duced }\end{array}$ & 7 & -8.43 & 0 & 7 & 2.57 & 0 & 23 & 0.902 \\
\hline & Early gestures & 7 & 1.86 & 1 & 7 & -0.27 & 0 & 9 & 0.053 \\
\hline & Later gestures & 7 & 2.71 & 1 & 7 & 0.86 & 1 & 26 & 0.902 \\
\hline & Total gestures & 7 & 4.57 & 1 & 7 & 0.57 & 1 & 18 & 0.456 \\
\hline
\end{tabular}

* CGI-I scores reflect results at Week 12 only; Vineland-II domain and composite values are standard scores; MSEL values are age equivalents

$A B C$ Aberrant Behavior Checklist; $A E$ age equivalent; CGI Clinical Global Impression-Improvement Scale; MCDI Macarthur-Bates Communicative Development Inventory; MSEL Mullen Scales of Early Learning; RBS Repetitive Behavior Scale-Revised; SSP Short Sensory Profile

intellectual disability, none have undergone rigorous psychometric testing in PMS as of yet.

In terms of dosing, most studies with intranasal oxytocin in ASD continue to use 24 IU, but there have been no dose response studies to establish the appropriate dosing for different ages or populations. Differential effects may also occur based on acute versus chronic dosing; both methods appear to enhance functional connectivity in adult wild-type mice, but repeated administration was associated with reduced social interaction and communication in at least one study [61]. Likewise, differential effects were evident in a recent clinical trial in adults with ASD using proton magnetic resonance spectroscopy such that chronic dosing was associated with significant reductions in medial prefrontal cortical $\mathrm{N}$-acetylaspartate and glutamate levels, whereas acute dosing was not [12]. Equally important, intranasal delivery is fraught with challenges, especially for severely impaired populations who do not reliably follow instructions. Several studies have established brain penetrance with intranasal oxytocin in ASD based on functional imaging studies, [7, $8,26,37,79]$, but participants were mostly adult males without comorbid intellectual disability. As such, differential effects across studies and sample populations may well relate to poorly controlled delivery and variability in absorption from the olfactory epithelium $[1,64]$. However, this variability does not appear to contribute to tolerability issues, and AEs did not differ between groups in the present study, a finding consistent with at least one large meta-analysis of reported AEs from clinical trials with intranasal oxytocin in ASD [20]. Also, worth noting, in the study with Shank3-deficient rats that served in part as the basis for this clinical trial, oxytocin was administered though intracerebroventricular injection and not intranasally [45]. Future studies might also control for baseline levels of oxytocin as variability in underlying oxytocin regulation may contribute to differential responses; individuals with lower pre-treatment oxytocin levels may show the greatest improvement in social responsiveness [62].

\section{Limitations}

Drawing definitive conclusions about the efficacy of oxytocin in PMS based on the results of this study is limited by our small sample size, a challenge inherent to studying rare disorders. In fact, we ended our trial after three years due to challenges with recruitment and perhaps stopped before enrolling an adequate sample size to detect small effects. Our dosing paradigm also did not account for the relatively broad age range, pubertal status, or baseline levels of oxytocin. In addition, despite adequate training on drug administration, six insufflations twice daily may have been challenging for some participants. Compliance was monitored using parent report and drug diaries, but given that our study drug was administered at home, it is possible that doses were missed or not properly administered. Further, the majority of our measures, including the primary outcome, rely on subjective parent reporting 
Table 3 Reported adverse events from randomization through week-12

\begin{tabular}{lll}
\hline Adverse events & Placebo & Oxytocin \\
\hline Sedation & $2(20 \%)$ & $1(12.5 \%)$ \\
Decreased appetite & $2(20 \%)$ & $0(0 \%)$ \\
Periorbital/facial swelling & $1(10 \%)$ & $0(0 \%)$ \\
Diarrhea & $1(10 \%)$ & $1(12.5 \%)$ \\
Upper respiratory tract infection & $2(20 \%)$ & $1(12.5 \%)$ \\
Sleep disturbance & $2(20 \%)$ & $5(62.5 \%)$ \\
Increased appetite & $1(10 \%)$ & $1(12.5 \%)$ \\
Irritability/agitation & $3(30 \%)$ & $1(12.5 \%)$ \\
Cough & $0(0 \%)$ & $1(12.5 \%)$ \\
Runny nose/congestion & $1(10 \%)$ & $0(0 \%)$ \\
Fever & $5(50 \%)$ & $2(25 \%)$ \\
Aggression/self-injury & $1(10 \%)$ & $0(0 \%)$ \\
Infection & $3(30 \%)$ & $2(25 \%)$ \\
Elated mood/silliness & $1(10 \%)$ & $3(37.5 \%)$ \\
Leg weakness & $1(10 \%)$ & $1(12.5 \%)$ \\
Restlessness/hyperactivity & $1(10 \%)$ & $5(62.5 \%)$ \\
Bloody nose & $0(0 \%)$ & $2(25 \%)$ \\
Stereotypies & $2(20 \%)$ & $1(12.5 \%)$ \\
Apathy & $0(0 \%)$ & $1(12.5 \%)$ \\
Foot pain & $1(10 \%)$ & $0(0 \%)$ \\
Hirsutism & $0(0 \%)$ & $1(12.5 \%)$ \\
Tooth pain & $0(0 \%)$ & $1(12.5 \%)$ \\
Eczema & $1(10 \%)$ & $1(12.5 \%)$ \\
Allergies/asthma & $2(20 \%)$ & $2(25 \%)$ \\
Enuresis & $1(10 \%)$ & $0(0 \%)$ \\
Accidental injury & $1(10 \%)$ & $0(0 \%)$ \\
Seizure & $1(10 \%)$ & $0(0 \%)$ \\
Rubbing ears & $1(10 \%)$ & $0(0 \%)$ \\
Disinhibited & $1(10 \%)$ & $0(0 \%)$ \\
Oppositional behavior & $2(20 \%)$ & $0(0 \%)$ \\
Low frustration tolerance & $1(10 \%)$ & $1(12.5 \%)$ \\
Tantrums & $41(12.5 \%)$ \\
Total & 35 \\
\hline
\end{tabular}

and have not been well validated for use in clinical trials in PMS. Finally, preclinical models benefit from genetic homogeneity and while all the individuals in our sample had SHANK3 haploinsufficiency, it was comprised of those with 22q13 deletions of varying sizes $(n=12)$, in addition to $S H A N K 3$ sequence variants $(n=6)$. However, the present study was too small to examine subset analyses but this may be a worthy endeavor for future studies.

\section{Conclusions}

While the results of this study must be interpreted with caution in light of the limitations, intranasal oxytocin does not appear efficacious in improving the core symptoms of ASD in children with PMS. Despite these findings and inconsistent results across studies, enthusiasm persists for oxytocin as a treatment for ASD symptoms. Future studies must address this complex multitude of confounding factors to advance oxytocin as a treatment in ASD and related neurodevelopmental disorders. In addition to genetics, other biomarkers, such as using electrophysiology, to stratify sample populations and attempt to predict treatment response have the potential to improve clinical trial designs. The development of new outcome measures, refined and validated for specific genetic forms of ASD, may also help. Importantly, outcome measures that incorporate objective assessments will be more likely to reduce bias. Finally, exploring novel mechanisms for intranasal delivery to enhance absorption in addition to clarifying optimal dosing regimens will be critical for future trial success. Nevertheless, a genetics-first approach and other methods to limit heterogeneity in clinical trial populations remain a promising path forward for studies in ASD and related neurodevelopmental disorders.

\footnotetext{
Abbreviations

ABC: Aberrant Behavior Checklist; ADI-R: Autism Diagnostic Interview-Revised; ADOS-2: Autism Diagnostic Observation Schedule, Second Edition; DSM-5: Diagnostic and Statistical Manual for Mental Disorders, Fifth Edition; AE: Age equivalent; AEs: Adverse events; ASD: Autism spectrum disorder; DQ: Developmental quotient; CGI-I: Clinical Global Impression-Improvement Scale; FDA: Food and Drug Administration; IU: International units; MCDI: MacarthurBates Communicative Development Inventory; MSEL: Mullen Scales of Early Learning; PMS: Phelan-McDermid syndrome; RBS-R: Repetitive Behavior ScaleRevised; SMURF: Safety monitoring report form; SSP: Short Sensory Profile; Vineland-II:Vineland Adaptive Behavior Scales.
}

\section{Supplementary Information}

The online version contains supplementary material available at https://doi. org/10.1186/s13229-021-00459-1.

Additional file 1: Supplementary Table 1: Mean values for all measures across groups at baseline and week 12 .

Additional file 2: figure 2. CONSORT diagram showing the flow of participants through Week 12

\section{Acknowledgements}

The authors would like to thank the families who participated and the PhelanMcDermid Syndrome Foundation for their support in recruitment.

\section{Authors' contributions}

JF and SS contributed to data analysis and manuscript writing; AK, JFF, YF, DH, PT, PS, and JZ contributed to study design, data collection, and manuscript writing; $\mathrm{CL}$ and $\mathrm{LT}$ collected and entered data for analysis; $\mathrm{HHN}$ and JDB contributed to manuscript writing. All authors read and approved the final manuscript

\section{Funding}

This study was supported in part by a grant from the Beatrice and Samuel A. Seaver Foundation. 


\section{Availability of data and materials}

The datasets used and/or analyzed during the current study are available from the corresponding author on reasonable request.

\section{Declarations}

Ethics approval and consent to participate

The protocol was approved by the Mount Sinai Program for the Protection of Human Subjects and all caregivers signed informed consent.

\section{Consent for publication}

Not applicable.

\section{Competing interests}

AK receives research support from AMO Pharma and consults to Acadia, Alkermes, and Ovid Therapeutics. JDB has a shared patent with Mount Sinai for IGF-1 in Phelan-McDermid syndrome. No other authors have competing interests to disclose.

\begin{abstract}
Author details
${ }^{1}$ Icahn School of Medicine at Mount Sinai, New York, NY, USA. ${ }^{2}$ Seaver Autism Center for Research and Treatment, Icahn School of Medicine at Mount Sinai, One Gustave L. Levy Place, Box 1230, New York, NY 10029, USA. ${ }^{3}$ Department of Psychiatry, Icahn School of Medicine at Mount Sinai, New York, NY, USA. ${ }^{4}$ Department of Neuroscience, Icahn School of Medicine at Mount Sinai, New York, NY, USA. ${ }^{5}$ Department of Pediatrics, Icahn School of Medicine at Mount Sinai, New York, NY, USA. ${ }^{6}$ Department of Medical Epidemiology and Biostatistics, Karolinska Institutet, Stockholm, Sweden. ${ }^{7}$ Department of Genetics and Genomic Sciences, Icahn School of Medicine at Mount Sinai, New York, NY, USA.
\end{abstract}

Received: 22 February 2021 Accepted: 19 July 2021

Published online: 30 September 2021

\section{References}

1. Alvares GA, Quintana DS, Whitehouse AJ. Beyond the hype and hope: Critical considerations for intranasal oxytocin research in autism spectrum disorder. Autism Res. 2017;10(1):25-41.

2. Aman MG, Singh NN, Stewart AW, Field CJ. The aberrant behavior checklist: a behavior rating scale for the assessment of treatment effects. Am J Ment Defic. 1985;89(5):485-91.

3. Aman MG, Singh NN. Supplement to Aberrant Behavior Checklist manual. East Aurora: Slosson Educational Publications; 1994.

4. American Psychiatric Association. Diagnostic and Statistical Manual of Mental Disorders (DSM- $5^{\circledR}$ ); American Psychiatric Publishing: Lansing. USA: Ml; 2013.

5. Anagnostou E, Soorya L, Chaplin W, et al. Intranasal oxytocin versus placebo in the treatment of adults with autism spectrum disorders: a randomized controlled trial. Mol Autism. 2012;3(1):16.

6. Andari E, Duhamel JR, Zalla T, Herbrecht E, Leboyer M, Sirigu A. Promoting social behavior with oxytocin in high-functioning autism spectrum disorders. Proc Natl Acad Sci USA. 2010;107(9):4389-94.

7. Aoki Y, Yahata N, Watanabe T, Takano Y, Kawakubo Y, Kuwabara H, Iwashiro N, Natsubori T, Inoue H, Suga M, Takao H, Sasaki H, Gonoi W, Kunimatsu A, Kasai K, Yamasue H. Oxytocin improves behavioural and neural deficits in inferring others' social emotions in autism. Brain. 2014;137(Pt 11):3073-86.

8. Aoki Y, Watanabe T, Abe O, Kuwabara H, Yahata N, Takano Y, Iwashiro N, Natsubori T, Takao H, Kawakubo Y, Kasai K, Yamasue H. Oxytocin's neurochemical effects in the medial prefrontal cortex underlie recovery of task-specific brain activity in autism: a randomized controlled trial. Mol Psychiatry. 2015;20(4):447-53.

9. Bartz JA, Nitschke JP, Krol SA, Tellier PP. Oxytocin selectively improves empathic accuracy: a replication in men and novel insights in women. Biol Psychiatry Cogn Neurosci Neuroimaging 2019;4(12):1042-1048.

10. Baskerville TA, Douglas AJ. Dopamine and oxytocin interactions underlying behaviors: potential contributions to behavioral disorders. CNS Neurosci Ther. 2010;16(3):e92-123. https://doi.org/10.1111/j.1755-5949. 2010.00154.x.
11. Baumgartner T, Heinrichs M, Vonlanthen A, Fischbacher U, Fehr E. Oxytocin shapes the neural circuitry of trust and trust adaptation in humans. Neuron. 2008;58(4):639-50.

12. Benner S, Aoki Y, Watanabe T, Endo N, Abe O, Kuroda M, Kuwabara H, Kawakubo Y, Takao H, Kunimatsu A, Kasai K, Bito H, Kakeyama M, Yamasue $H$. Neurochemical evidence for differential effects of acute and repeated oxytocin administration. Mol Psychiatry. 2021;26(2):710-20.

13. Bodfish JW, Symons FJ, Parker DE, Lewis MH. Varieties of repetitive behavior in autism: comparisons to mental retardation. J Autism Dev Disord. 2000;30(3):237-43.

14. Boeckers TM. The postsynaptic density. Cell Tissue Res. 2006;362:409-22.

15. Bonaglia MC, Giorda R, Mani E, Aceti G, Anderlid BM, Barconcini A, Pramparo T, Zuffardi O. Identification of a recurrent breakpoint within the SHANK3 gene in the 22q13.3 deletion syndrome. J Med Genet. 2006;10:822-8.

16. Bonaglia MC, Giorda R, Beri S, De Agostini C, et al. Molecular mechanisms generating and stabilizing terminal $22 q 13$ deletions in 44 subjects with Phelan/McDermid syndrome. PLoS Genet. 2011;7(7).

17. Bozdagi, O, Sakurai, T, Papapetrou, D, Wang, X, Dickstein, DL, Takahashi, N, Kajiwara, Y, Yang, M, Katz, AM, Scattoni, ML, Harris, MJ, Saxena, R, Silverman, JL, Crawley, JN, Zhou, Q, Hof, PR, Buxbaum JD. Halpoinsufficiency of the autism-associated SHANK3 gene leads to deficits in synaptic function, social interaction, and social communication. Mol Autism. 2010;1-15.

18. Braida D, et al. Neurohypophyseal hormones manipulation modulate social and anxiety-related behavior zebrafish. Psychopharmacology. 2012;220:319-30

19. Brown EC, Aman MG, Havercamp SM. Factor analysis and norms for parent ratings on the Aberrant Behavior Checklist-Community for young people in special education. Res Dev Disabil. 2002;23(1):45-60.

20. Cai Q, Feng L, Yap KZ. Systematic review and meta-analysis of reported adverse events of long-term intranasal oxytocin treatment for autism spectrum disorder. Psychiatry Clin Neurosci. 2018;72(3):140-51.

21. Chang SW, Platt ML. Oxytocin and social cognition in rhesus macaques: implications for understanding and treating human psychopathology. Brain Res. 2014;1580:57-68.

22. De Dreu CK, Greer LL, Handgraaf MJ, Shalvi S, Van Kleef GA, Baas M, Ten Velden FS, Van Dijk E, Feith SW. The neuropeptide oxytocin regulates parochial altruism in intergroup conflict among humans. Science. 2010;328(5984):1408-11.

23. Di Simplicio M, Massey-Chase R, Cowen PJ, Harmer CJ. Oxytocin enhances processing of positive versus negative emotional information in healthy male volunteers. J Psychopharmacol. 2009;23(3):241-8.

24. Ditzen B, Schaer M, Gabriel B, Bodenmann G, Ehlert U, Heinrichs M. Intranasal oxytocin increases positive communication and reduces cortisol levels during couple conflict. Biol Psychiatry. 2009;65(9):728-31.

25. Domes G, Lischke A, Berger C, Grossmann A, Hauenstein K, Heinrichs M, Herpertz SC. Effects of intranasal oxytocin on emotional face processing in women. Psychoneuroendocrinology. 2010;35(1):83-93.

26. Domes G, Heinrichs M, Kumbier E, Grossmann A, Hauenstein K, Herpertz SC. Effects of intranasal oxytocin on the neural basis of face processing in autism spectrum disorder. Biol Psychiatry. 2013;74(3):164-71.

27. Domes G, Kumbier E, Heinrichs M, Herpertz SC. Oxytocin promotes facial emotion recognition and amygdala reactivity in adults with asperger syndrome. Neuropsychopharmacology. 2014;39(3):698-706.

28. Dumais KM, Veenema AH. Vasopressin and oxytocin receptor systems in the brain: Sex differences and sex-specific regulation of social behavior. Front Neuroendocrinol. 2016;40:1-23.

29. Durand CM, Betancur C, Boeckers TM, Bockmann J, Chaste P, Fauchereau F, Nygren G, Rastam M, Gillberg IC, Anckarsäter H, Sponheim E, GoubranBotros H, Delorme R, Chabane N, Mouren-Simeoni MC, de Mas P, Bieth E, Rogé B, Héron D, Burglen L, Gillberg C, Leboyer M, Bourgeron T. Mutations in the gene encoding the synaptic scaffolding protein SHANK3 are associated with autism spectrum disorders. Nat Genet. 2007;39(1):25-7.

30. Dunn, W. Sensory Profile. The Psychological Corporation. 1999.

31. Farmer C, Golden C, Thurm A. Concurrent validity of the differential ability scales, second edition with the Mullen Scales of Early Learning in young children with and without neurodevelopmental disorders. Child Neuropsychol. 2016;22(5):556-69.

32. Fenson L, Dale PS, Reznick JS, Thal DJ, Bates E, Hartung JP, Pethick S, Reilly JS. MacArthur communicative development inventories: user's guide and technical manual. Baltimore: Paul H. Brokes Publishing Co.; 1993. 
33. Fenson, L, Marchman, VA, Thal, DJ, Dale, PS, Reznick, JS, Bates, E. MacArthur-Bates communicative development inventories: user's guide and technical manual (2nd ed.) Baltimore: Paul H. Brooks Publishing Co. 2007.

34. Fischer-Shofty M, Shamay-Tsoory SG, Levkovitz Y. Characterization of the effects of oxytocin on fear recognition in patients with schizophrenia and in healthy controls. Front Neurosci. 2018;7:127.

35. Gabor CS, Phan A, Clipperton-Allen AE, Kavaliers M, Choleris E. Interplay of oxytocin, vasopressin, and sex hormones in the regulation of social recognition. Behav Neurosci. 2012;126(1):97-109.

36. Gimple G, Fahrenholz F. The Oxytocin Receptor System: Structure, Function, and Regulation. Physiol Rev. 2001;81(2):629-83.

37. Gordon I, Vander Wyk BC, Bennett RH, Cordeaux C, Lucas MV, Eilbott JA, Zagoory-Sharon O, Leckman JF, Feldman R, Pelphrey KA. Oxytocin enhances brain function in children with autism. Proc Natl Acad Sci USA. 2013;110(52):20953-8.

38. Guastella AJ, Mitchell PB, Mathews F. Oxytocin enhances the encoding of positive social memories in humans. Biol Psychiatry. 2008;64(3):256-8.

39. Guastella AJ, Mitchell PB, Dadds MR. Oxytocin increases gaze to the eye region of human faces. Biol Psychiatry. 2008;63(1):3-5.

40. Guastella AJ, Gray KM, Rinehart NJ, Alvares GA, Tonge BJ, Hickie IB, Keating CM, Cacciotti-Saija C, Einfeld SL. The effects of a course of intranasal oxytocin on social behaviors in youth diagnosed with autism spectrum disorders: a randomized controlled trial. J Child Psychol Psychiatry. 2015:56(4):444-52.

41. Guastella AJ, Einfeld SL, Gray KM, et al. Intranasal oxytocin improves emotion recognition for youth with autism spectrum disorders. Biol Psychiatry. 2010;67(7):692-4.

42. Guo B, Chen J, Chen Q, Ren K, Feng D, Mao H, Yao H, Yang J, Liu H, Liu Y, Jia F, Qi C, Lynn-Jones T, Hu H, Fu Z, Feng G, Wang W, Wu S. Anterior cingulate cortex dysfunction underlies social deficits in Shank3 mutant mice. Nat Neurosci. 2019;22(8):1223-34.

43. Guy W. ECDEU Assessment Manual for Psychopharmacology-Revised (DHEW Publ No ADM 76-338). Rockville, MD, U.S. Department of Health, Education, and Welfare, Public Health Service, Alcohol, Drug Abuse, and Mental Health Administration, NIMH Psychopharmacology Research Branch, Division of Extra-mural Research Programs. 1976;218-222.

44. Harony-Nicolas H, De Rubeis S, Kolevzon A, Buxbaum JD. Phelan McDermid syndrome: from genetic discoveries to animal models and treatment. J Child Neurol. 2015;30(14):1861-70.

45. Harony-Nicolas H, Kay M, du Hoffmann J, Klein ME, Bozdagi-Gunal O, Riad M, Daskalakis NP, Sonar S, Castillo PE, Hof PR, Shapiro ML, Baxter MG, Wagner S, Buxbaum JD. Oxytocin improves behavioral and electrophysiological deficits in a novel Shank3-deficient rat. Elife. 2017;6:e18904.

46. Hettmansperger T, McKean J. Robust Nonparametric Statistical Methods, Second Edition. 2nd ed. 2010.

47. Jacot-Descombes S, Keshav NU, Dickstein DL, Wicinski B, Janssen WGM, Hiester LL, Sarfo EK, Warda T, Fam MM, Harony-Nicolas H, Buxbaum JD, Hof PR, Varghese M. Altered synaptic ultrastructure in the prefrontal cortex of Shank3-deficient rats. Mol Autism. 2020;11(1):89.

48. Javed S, Selliah T, Lee YJ, Huang WH. Dosage-sensitive genes in autism spectrum disorders: from neurobiology to therapy. Neurosci Biobehav Rev. 2020;118:538-67.

49. Kéri S, Benedek G. Oxytocin enhances the perception of biological motion in humans. Cogn Affect Behav Neurosci. 2009;9(3):237-41.

50. Kimura T, Tanizawa O, Mori K, Brownstein MJ, Okayama H. Structure and expression of a human oxytocin receptor. Nature. 1992;356(6369):526-9.

51. Kosfeld M, Heinrichs M, Zak PJ, Fischbacher U, Fehr E. Oxytocin increases trust in humans. Nature. 2005;435(7042):673-6.

52. Kubota Y, et al. Structure and expression of the mouse oxytocin receptor gene. Mol Cell Endocrinol. 1996;124:25-32.

53. Leblond CS, Nava C, Polge A, Gauthier J, Huguet G, Lumbroso S, Giuliano F, Stordeur C, Depienne C, Mouzat K, Pinto D, Howe J, Lemière N, Durand CM, Guibert J, Ey E, Toro R, Peyre H, Mathieu A, Amsellem F, Rastam M, Gillberg IC, Rappold GA, Holt R, Monaco AP, Maestrini E, Galan P, Heron D, Jacquette A, Afenjar A, Rastetter A, Brice A, Devillard F, Assouline B, Laffargue F, Lespinasse J, Chiesa J, Rivier F, Bonneau D, Regnault B, Zelenika D, Delepine M, Lathrop M, Sanlaville D, Schluth-Bolard C, Edery P, Perrin L, Tabet AC, Schmeisser MJ, Boeckers TM, Coleman M, Sato D, Szatmari P, Scherer SW, Rouleau GA, Betancur C, Leboyer M, Gillberg C, Delorme $\mathrm{R}$, Bourgeron T. Meta-analysis of SHANK Mutations in Autism Spectrum
Disorders: a gradient of severity in cognitive impairments. PLoS Genet. 2014;10(9):e1004580. https://doi.org/10.1371/journal.pgen.1004580.

54. Leng G, Ludwig M. Intranasal oxytocin: myths and delusions. Biol Psychiatry. 2016;79(3):243-50.

55. Lord C, Rutter M, Le Couteur A. Autism diagnostic interview-revised: a revised version of a diagnostic interview for caregivers of individuals with possible pervasive developmental disorders. J Autism Dev Disord. 1994;24:659-85.

56. Lord C, Rutter M, DiLavore PC, Risi S, Gotham K, Bishop D. The autism diagnostic observation schedule, second edition (ADOS-2) manual (Part 1): Modules 1-4. Torrance, CA: Western Psychological Services; 2012.

57. Mullen E. Mullen scales of early learning. Circle Pines: American Guidance Service; 1989.

58. Mitre $\mathrm{M}$, et al. A distributed network for social cognition enriched for oxytocin receptors. J Neurosci. 2016;36:2517-35.

59. Monteiro P, Feng G. SHANK proteins: roles at the synapse and in autism spectrum disorder. Nat Rev Neurosci. 2017;18(3):147-57.

60. Mossink B, Negwer M, Schubert D, Nadif Kasri N. The emerging role of chromatin remodelers in neurodevelopmental disorders: a developmental perspective. Cell Mol Life Sci. 2020.

61. Pagani M, De Felice A, Montani C, Galbusera A, Papaleo F, Gozzi A. Acute and repeated intranasal oxytocin differentially modulate brain-wide functional connectivity. Neuroscience. 2020;445:83-94.

62. Parker KJ, Oztan O, Libove RA, Sumiyoshi RD, Jackson LP, Karhson DS, Summers JE, Hinman KE, Motonaga KS, Phillips JM, Carson DS, Garner JP, Hardan AY. Intranasal oxytocin treatment for social deficits and biomarkers of response in children with autism. Proc Natl Acad Sci USA. 2017;114(30):8119-24.

63. Petrovic P, Kalisch R, Singer T, Dolan RJ. Oxytocin attenuates affective evaluations of conditioned faces and amygdala activity. J Neurosci. 2008;28(26):6607-15.

64. Quintana DS, Alvares GA, Hickie IB, Guastella AJ. Do delivery routes of intranasally administered oxytocin account for observed effects on social cognition and behavior? A two-level model. Neurosci Biobehav Rev. 2015;49:182-92.

65. Reichova A, Bacova Z, Bukatova S, Kokavcova M, Meliskova V, Frimmel K, Ostatnikova D, Bakos J. Abnormal neuronal morphology and altered synaptic proteins are restored by oxytocin in autism-related SHANK3 deficient model. Mol Cell Endocrinol. 2020;518:110924.

66. Richard P, Moos F, Freund-Mercier MJ. Central effects of oxytocin. Physiol Rev. 1991;71(2):331-70.

67. Rimmele U, Hediger $K$, Heinrichs M, Klaver P. Oxytocin makes a face in memory familiar. J Neurosci. 2009;29(1):38-42.

68. Savaskan E, Ehrhardt R, Schulz A, Walter M, Schächinger H. Post-learning intranasal oxytocin modulates human memory for facial identity. Psychoneuroendocrinology. 2008;33(3):368-74.

69. Sikich $L$, on behalf of ACE SOARS Network, (2019). SOARS-B: A large, phase II RCT of daily oxytocin in ASD for enhancing reciprocal social behaviors. 66th Annual Meeting of the American Academy of Child and Adolescent Psychiatry, October 19th, 2019, Chicago, IL.

70. Song TJ, Lan XY, Wei MP, Zhai FJ, Boeckers TM, Wang JN, Yuan S, Jin MY, Xie YF, Dang WW, Zhang C, Schön M, Song PW, Qiu MH, Song YY, Han SP, Han JS, Zhang R. Altered Behaviors and Impaired Synaptic Function in a Novel Rat Model With a Complete Shank3 Deletion. Front Cell Neurosci. 2019:13:111.

71. Soorya L, Kolevzon A, Zweifach J, Lim T, Dobry Y, Schwartz L, Frank Y, Wang AT, Cai G, Parkhomenko E, Halpern D, Grodberg D, Angarita B, Willner JP, Yang A, Canitano R, Chaplin W, Betancur C, Buxbaum JD. Prospective investigation of autism and genotype-phenotype correlations in 22q13 deletion syndrome and SHANK3 deficiency. Mol Autism. 2013;4(1):18.

72. Soorya L, Leon J, Trelles MP, Thurm A. Framework for assessing individuals with rare genetic disorders associated with profound intellectual and multiple disabilities (PIMD): the example of Phelan McDermid Syndrome. Clin Neuropsychol. 2018;32(7):1226-55.

73. Sparrow, SS, Balla, DA, and Cicchetti, DV, Vineland adaptive behaviour scales: a revision of the vineland social maturity scale by Edgar A. Doll. Circle-Pines, MN: American Guidance Service. 1984.

74. Tachibana M, Kagitani-shimono K, Mohri I, et al. Long-term administration of intranasal oxytocin is a safe and promising therapy for early adolescent 
boys with autism spectrum disorders. J Child Adolesc Psychopharmacol. 2013;23(2):123-7.

75. Theodoridou A, Rowe AC, Penton-Voak IS, Rogers PJ. Oxytocin and social perception: oxytocin increases perceived facial trustworthiness and attractiveness. Horm Behav. 2009;56(1):128-32.

76. Unkelbach C, Guastella AJ, Forgas JP. Oxytocin selectively facilitates recognition of positive sex and relationship words. Psychol Sci. 2008;19(11):1092-4.

77. Varghese M, Keshav N, Jacot-Descombes S, Warda T, Wicinski B, Dickstein DL, Harony-Nicolas H, De Rubeis S, Drapeau E, Buxbaum JD, Hof PR. Autism spectrum disorder: neuropathology and animal models. Acta Neuropathol. 2017;134(4):537-66.

78. Veening JG, Olivier B. Intranasal administration of oxytocin: behavioral and clinical effects, a review. Neurosci Biobehav Rev. 2013;37(8):1445-65. https://doi.org/10.1016/j.neubiorev.2013.04.012.

79. Watanabe T, Abe O, Kuwabara H, Yahata N, Takano Y, Iwashiro N, Natsubori T, Aoki Y, Takao H, Kawakubo Y, Kamio Y, Kato N, Miyashita Y, Kasai $\mathrm{K}$, Yamasue $\mathrm{H}$. Mitigation of sociocommunicational deficits of autism through oxytocin-induced recovery of medial prefrontal activity: a randomized trial. JAMA Psychiat. 2014;71(2):166-75.
80. Wilcoxon F. Individual comparisons by ranking methods. Biometrics Bulletin. 1945;6:80-3.

81. Yang M, Bozdagi O, Scattoni ML, et al. Reduced excitatory neurotransmission and mild autism-relevant phenotypes in adolescent Shank3 null mutant mice. J Neurosci. 2012;32(19):6525-41.

82. Yatawara CJ, Einfeld SL, Hickie IB, Davenport TA, Guastella AJ. The effect of oxytocin nasal spray on social interaction deficits observed in young children with autism: a randomized clinical crossover trial. Mol Psychiatry. 2016;21(9):1225-31.

83. Zak PJ, Kurzban R, Matzner WT. Oxytocin is associated with human trustworthiness. Horm Behav. 2005;48(5):522-7.

84. Zatkova M, Reichova A, Bacova Z, Strbak V, Kiss A, Bakos J. Neurite outgrowth stimulated by oxytocin is modulated by inhibition of the calcium voltage-gated channels. Cell Mol Neurobiol. 2018;38(1):371-8.

\section{Publisher's Note}

Springer Nature remains neutral with regard to jurisdictional claims in published maps and institutional affiliations.
Ready to submit your research? Choose BMC and benefit from:

- fast, convenient online submission

- thorough peer review by experienced researchers in your field

- rapid publication on acceptance

- support for research data, including large and complex data types

- gold Open Access which fosters wider collaboration and increased citations

- maximum visibility for your research: over $100 \mathrm{M}$ website views per year

At BMC, research is always in progress.

Learn more biomedcentral.com/submissions 